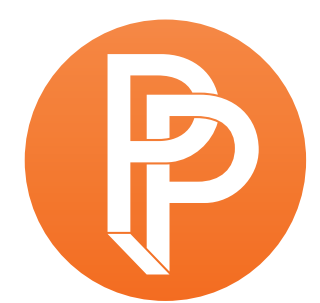

PERFORMANCE

PHILOSOPHY

\title{
THE PERFORMER AS PHILOSOPHER AND DIPLOMAT OF DISSENSUS: \\ THINKING AND DRINKING TEA WITH BENJAMIN VERDONCK IN BARA/KE(2000)
}

\section{CHRISTEL STALPAERT GHENT UNIVERSITY}

Ecology and activism is a burning issue in theatre and performance studies. Since guest-editor Una Chaudhuri chose eco-theatre as the title for a thematic issue of the journal Theater in 1994, the topic is booming. As Wendy Arons notes, Chaudhuri "called upon theatre artists and scholars to play a role in the transvaluation of ideas, metaphors, and approaches to the environment that is necessary to avert ecological crisis" (Arons 2007, 689). However, following the French philosopher Bruno Latour, a radically new encounter with ecology is needed today, if eco-activism still wants to have a future. It seems that, in order to survive, eco-activism and eco-art have to move beyond their narrow and limited anthropocentric perspective and to renounce the (Romantic) discourse of mourning. In this paradigm shift, the performer as philosopher - in the sense of a diplomat of dissensus - might play an important role.

The Flemish artist and performer Benjamin Verdonck picks up this role of a performer as philosopher. In his artistic tree houses, Verdonck invites passers-by for coffee or tea and gently raises ecological issues. His particular posthuman eco-activist and philosophical labour points at a paradigm shift in the performing praxis of ecological protest in comparison with the Romantic era on the one hand and with eco-activism of the sixties, seventies and eighties on the other. Verdonck performs protest as what I call "a diplomat of dissensus", combining Latour's writings on contemporary ecology and the function of the diplomat therein, and Jacques Rancière's writings on dissensus and art in public space. Verdonck's posthuman perspective on ecology inaugurates a mode of activism as "a distributed agency with vibrant matter" - to put it in Jane Bennett's words 
(Bennett 2009, 7). Ecology, for its part, moves into the direction of what Félix Guattari in The Three Ecologies refers to as "the ethico-aesthetic aegis of an ecosophy" (Guattari 2000, 41), a contraction of ecology and philosophy that connects the environmental with a reflection on the psychic production of subjectivity and social relations.

To make my argument, I will first outline the performing praxis of ecological protest in the Romantic era on the one hand and of eco-activism of the sixties, seventies and eighties on the other. After that, I will outline how Verdonck performs protest as what I call "a diplomat of dissensus".

\section{Romantic Discourse of Reclusive Life}

In Rêveries du promeneur solitaire (Reveries of the Solitary Walker, published posthumously in 1782), writer and philosopher Jean-Jacques Rousseau (1712-1778) epitomized a retour à la nature movement. In his essay "Discours sur les sciences et les arts", he argues that the increase of knowledge is directly proportional to the waning of norms and values in a society. Primitive peoples, he finds, are closer to nature and consequently lead more 'authentic' and meaningful lives. Rousseau lamented the cold and soulless life in a city pervaded with technology and industry and suggested that writers and artists should, much like monks, live in solitude, close to nature, as primitive men did, to experience the benefits of overwhelming natural surroundings. Through a passionate, emotional desire for union with Nature, mirroring the communion of the mystic soul of the past with God, the artist-genius should deliberately retreat from society and settle into a sombre state of solitude and melancholic receptivity. In doing so, the artist-genius would lead a more 'authentic' and meaningful life, retiring from the 'wicked' city and retreating to the unadulterated beauty of nature and the charming natural life in the country.

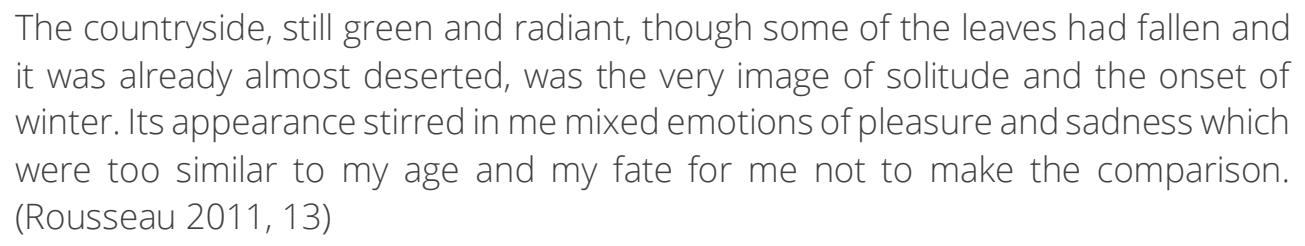

The American author Henry David Thoreau (1817-1862) had a similar ambition to shake off the modernist dead wood of life through a simple, primitive existence. He wrote his Walden, or Life in the Woods (1854) in a cabin located a mile outside his native village of Concord. While living in the hut for about two years, self-sufficiently though not without visitors, he wrote about the Romantic urge for a reclusive life in nature.

It would be some advantage to live a primitive and frontier life, though in the midst of an outward civilization, if only to learn what are the gross necessaries of life and what methods have been taken to obtain them. (Thoreau 1995, 7) 
Thoreau pities his contemporaries who slavishly go about their everyday business, perpetually in haste. Much like Rousseau, he strives toward self-knowledge through simplicity and urges everyone to keep in touch with wild, unspoiled nature:

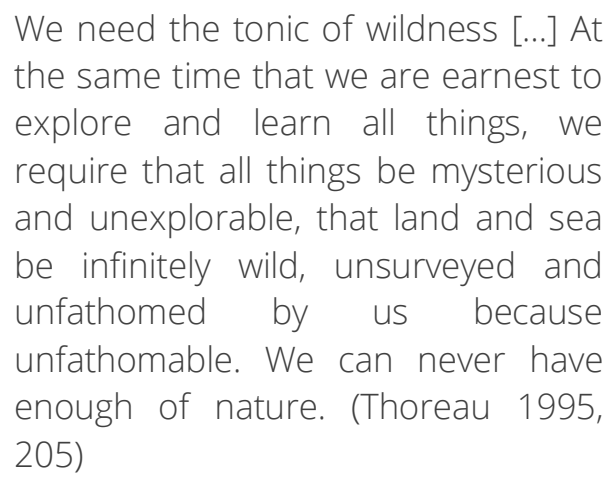

WALDEN;

ox,

LIFE IN THE WOODS.

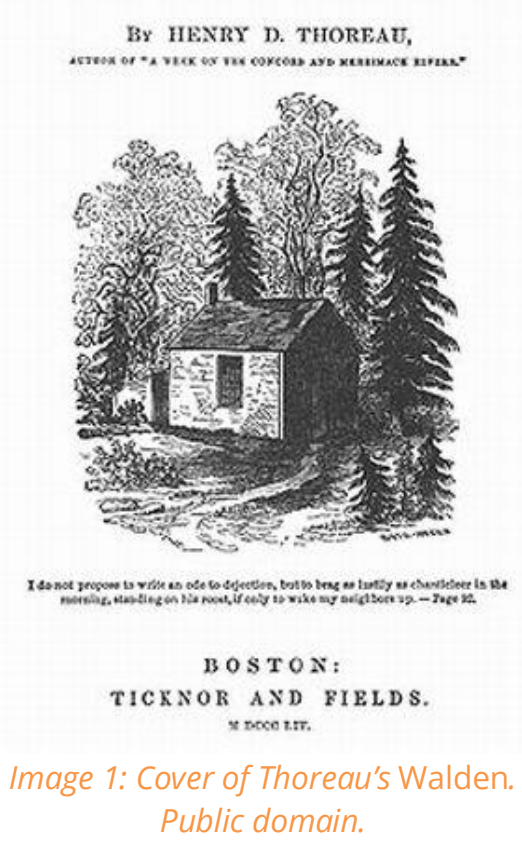

Eco-activism

As Karolien Byttebier and I have pointed out in a joint publication on art and eco-activism (Stalpaert and Byttebier, 2014), early traces of eco-activism can be found in the painters of the Barbizon school, who were inspired by Rousseau's Romantic and 'primitivist' discourse. These artists also look upon industrialization with sorrow and gathered in the natural surroundings of Barbizon between 1830 and 1875, a village near Paris, at the edge of Fontainebleu forest. Théodore Rousseau portrayed the magnificent trees of this forest in his painting Lisière des Monts-Gérard, forêt de Fontainebleau (The Edge of the Woods at Monts-Girard, Fontainebleau Forest, 1852-1854). Strikingly, however, Rousseau not only depicted the majesty of nature but also the destructive work of lumbermen (Shackelford and Wissman 2002, 79; see also Stalpaert and Byttebier 2014). Here, Rousseau revealed his ecological-activist side avant la lettre. When their cherished forest was threatened, the Barbizon group actually succeeded in convincing Napoleon III to make the ancient oak woods a preserve (Amory 2007).

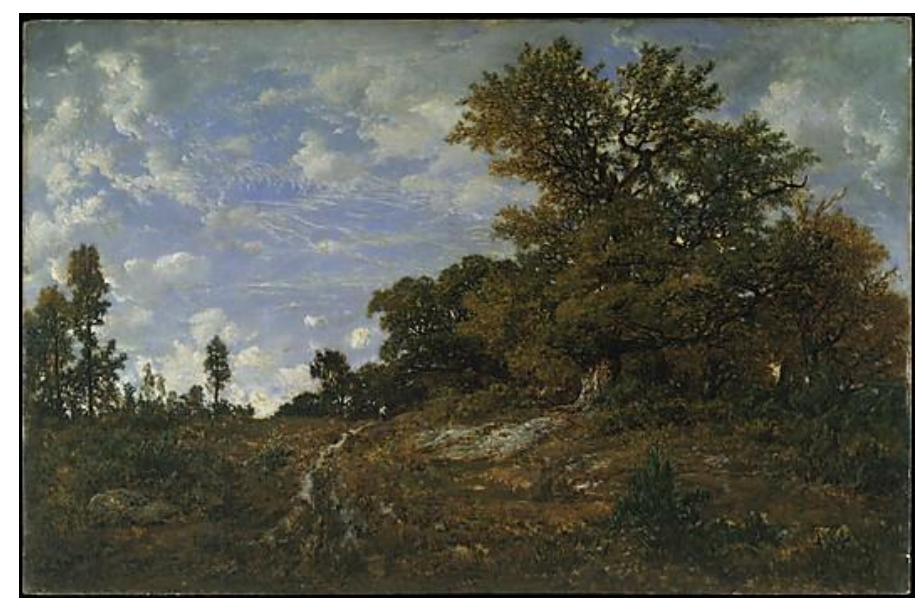

Image 2: Théodore Rousseau. 1852-1854. The Edge of the Woods at Monts-Girard, Fontainebleau Forest. (C) Metropolitan Museum of Art. All rights reserved. 
Surprisingly enough, and in this respect much like the case with the French school of Barbizon, it was the aesthetic (more than political or scientific) arguments of the American Hudson River School and its members that helped to create national parks at that time. The Yellowstone national park, for instance, is reported to owe its existence largely to Thomas Moran's paintings (Van Dyke 2008, 10; see also Stalpaert and Byttebier 2014).

However, it is not until the 1960s that the term 'ecology' comes to have explicit activist and environmental overtones. ${ }^{1}$ Mainly in America, the term loses its exclusively scientific connotation and ecology is gradually associated more with man's responsibility towards nature and its preservation, with care for the environment. From the sixties onwards, the term 'eco-' is more and more associated with activism, whilst the term 'ecology' has become "vaguely synonymous with 'environmentalism', even though for decades it was used exclusively to refer to a formal scientific pursuit" (Keller and Golley 2000, 3).

Well-known practices of performing protest conducted by these eco-activists are the 'tree sits'. Earth First!, for example - a radical environmental activist group that was founded in the USA in 1980 - inaugurated many of these tree-sitting blockade actions. Some lasted for a couple of days, some lasted for an hour. On May 23, 1985, Mike Jakubal organised the first Earth First! tree sit. Environmental activists sat at the base of a tree in support of its preservation, to prevent it from being cut down. Jakubal's tree-sitting concept has been adopted worldwide and has become an icon of eco-activism (Frances Lee 1995, 87). One of the most famous examples is the tree sit by activist Julia 'Butterfly' Hill, who spent two years in a 1500-year-old Redwood California tree to save it from being cut by the Pacific Lumber Company. For 738 days, between December 10, 1997, and December 18, 1999, this activist lived up in the tree. She supported benefit concerts and became an in-tree correspondent for a cable television channel, inviting and filming friends who visited her, even hosting TV-crews in 'her' tree, by that time called Luna (Gay 2012, 294-298).

The discourse of this eco-activism - also called "green rage" (Manes 1990) is primarily associated with civil disobedience and direct action, and with clear aims: unmaking civilization, or at least obstructing capitalist powers to proceed with their nature-unfriendly activities. The sometimes violent agenda of these groups is also apparent in the vocabulary being used to describe these protest groups, such as "eco-warriors" 2 or even "eco-terror". ${ }^{3}$ Its method is provocative: direct action; and its language is instructive, clear and simple. In this eco-activist labour, a 'we' is clearly demarcated versus an evil 'them'. The slogans supporting the eco-actions and these protest marches are commands with big exclamation marks, intended to persuade and convince people to join the 'we' in actually doing something about the situation. "No compromise" is the big motto. ${ }^{4}$

The artists who aligned themselves with these environmental protests, in the sixties, seventies and eighties, also adapted this discourse (see Stalpaert and Byttebier 2014). A famous example are the environmental actions that Genevieve Thomson Fraser conducted shortly after her graduation in theatre studies, when she coordinated the Acid Rain Awareness Weeks (1985) and organized the festivities for the Massachusetts State Forest and Parks System centennial to promote Forest Chautauqua (1997). With the drama text Giants in the Wilderness, the activist mode of her theatre 
praxis is clear: "It is time for the public (...) to take note", Fraser exclaimed, pointing at her hope to heighten the audience's environmental awareness and to instruct the audience to take direct action.

This kind of eco-activism still has its value in contemporary society; it raises awareness and inaugurates prompt action. However, a paradigm shift in contemporary eco-activist labour and aesthetics is taking place.

\section{Posthuman Eco-Artists as Diplomats of Dissensus}

In the twenty-first century, a new ethico-aesthetic is being developed with regard to ecology and environment. In Politics of Nature (2004), the French philosopher Bruno Latour is convinced that a "thoroughgoing rethinking of ecology" (2) is needed, if political ecology still wants to have a future. Latour reproaches both militant ecology - the practice of 'green' ecology movements - and the philosophy of ecology - the theory of that militant practice - of dictating "moral conduct in the place of ethics: apolitical, they decide on policy in place of politics" (19). Latour even calls the current philosophy of ecology Naturpolitik, referring of course to the notion of Realpolitik. Political ecology, he claims, "at least in its theory, has to let go of nature" (9). Following his thoughts, it seems that in order to survive - eco-art has to renounce the (Romantic) discourse of mourning. Ecology theorist Timothy Morton similarly urges us to exit "the unhappy consciousness he calls the Beautiful Soul, an attitude derived from Romantic thought" (paraphrased in Kelleher 2013, 28). Performance scholars Peggy Phelan and Una Chaudhuri also observed in their plenary dialogue at the PSi conference in Stanford in 2013, that the discourse of mourning and nostalgia in eco-art is exhausted; it is simply impossible to go back to a 'natural state' or a 'lost paradise' and there is no use in sticking to that unattainable image (Phelan and Chaudhuri 2013). According to Phelan, "'the pressure on the now' becomes one of the challenges and opportunities for contemporary art engaged with ecology". It is the 'now' to which performances should address its deepest ecological questions. Site-specificity, then, must be reread and revisited, not only in terms of time, but also in terms of space. ${ }^{5}$ In other words, setting the artistic event in a site-specific 'natural' environment, without problematizing the conception of a 'natural' state is problematic in itself, for nature and culture are not separable. As Čičigoj put it:

\section{Going back to nature is not an available option (if such a state ever existed at all) and probably not even a desirable one (civilisation is for Rousseau, after all, not only an anomaly of human nature but also its functional product). (Čičigoj 2013, 39)}

Furthermore, as Chaudhuri observes, the logic of climate change is not a spatial one. It is dependent on choices in different parts of the world simultaneously. Hence, a contemporary ecoartist should at least take into consideration these new spatial and temporal ecological conditions, rather than sticking to ideal images of a lost past.

As Latour observes in Politics of Nature, recent ecological crises, like for instance the mad cow disease, unlike their predecessors "have no clear boundaries, no well-defined essences, no sharp 
separation between their own hard kernel and their environment" (Latour 2004, 24). This is in stark contrast with one of the last "modernist" ecological crises like the case of asbestos. Even though it took ages to track down the causes, it became eventually clear that the asbestos, once an ideal material to work with, caused longue cancer. Contemporary ecological crises, however, are a rhizome network; with their producers being invisible, and their "numerous connections (...) that link them in many different ways to beings" (24).

Latour for that reason proposes to put an end to the old dichotomy between nature and society and urges political ecology to operate from within a complex collective or community, incorporating humans and nonhumans.

\begin{abstract}
Political ecology does no shift attention from the human pole to the pole of nature; it shifts from certainty about the production of risk-free objects (with their clear separation between things and people) to uncertainty about the relations whose unintended consequences threaten to disrupt all orderings, all plans, all impacts. What it calls back into question with such remarkable effectiveness is precisely the possibility of collecting the hierarchy of actors and values, according to an order fixed once and for all. (Latour 2004, 25)
\end{abstract}

This means that an entangled mesh of interdependent beings, a coexistence of all life forms, the "vast, sprawling mesh of interconnection without a definite center or edge" (Morton 2010, 8) is the ground and also the object of contemporary ecological thought. In this complex collectivity, ecoartists should shake of the role of ecological philosophers in the sense of Naturpolitik. Instead, they might take up the role of philosophers in the sense of posthuman 'diplomats of dissensus'; these are not outside experts possessing Knowledge and claiming absolute reason. On the contrary, they are flexible and open to experimentation and negotiation.

In what follows, I will observe this paradigm shift in eco-art: from an activist counter-culture or militant ecology to the cultivation of ecological thought as posthuman diplomacy in dissensus. In my view, Benjamin Verdonck is a contemporary eco-artist who assumes this role of the philosopher as diplomat. With his artistic tree houses, he does not merely provide the theory of a militant practice; rather, he revisits site-specificity and engages with the environment in a new, diplomatic way.

For his long durational and site-specific art project called Bara/ke (2000), Verdonck lived seven metres above ground for fourteen days in a self-constructed pile dwelling, in the middle of the Bara Square in Brussels, an intervention he later repeated on a square in Antwerp. ${ }^{6}$ He operates in the 'now' and looks at the future from there, trying to overcome idealized images of the past. Verdonck's tree houses are reminiscent of Henry David Thoreau's cabin and hence of the Romantics' sublimation of reclusive life in nature, as described in his book Walden. However, he recasts the hut in an urban environment. A gigantic reprint of an exotic 'natural' place functions as an ironic remainder/reminder of the discourse of Romantic sublimation, of our idealized but unattainable 'image' of a 'lost' origin. 
This of course inaugurates a different alignment with philosophy and ecology; Verdonck does not retreat into isolation but engages with the things and people within the interconnected mesh of the collective he encounters in the present. Verdonck's ten-day residency on the Bara-square was accompanied by activities for local residents, passers-by and tourists. Open breakfasts, mini-concerts, billboard announcements, performances, a shared meal during the Sunday market, and a daily press-campaign were all part of his intervention.

Over the course of this long durational performance, a particular narrative developed; a narrative that came about by interconnecting with passers-by and things that were randomly collected from the environment. The artwork Bara/ke consists mainly of "conversations with people passing by" as Verdonck "ate pastry and drank coffee with visitors all day" (Verdonck 2008, 64).

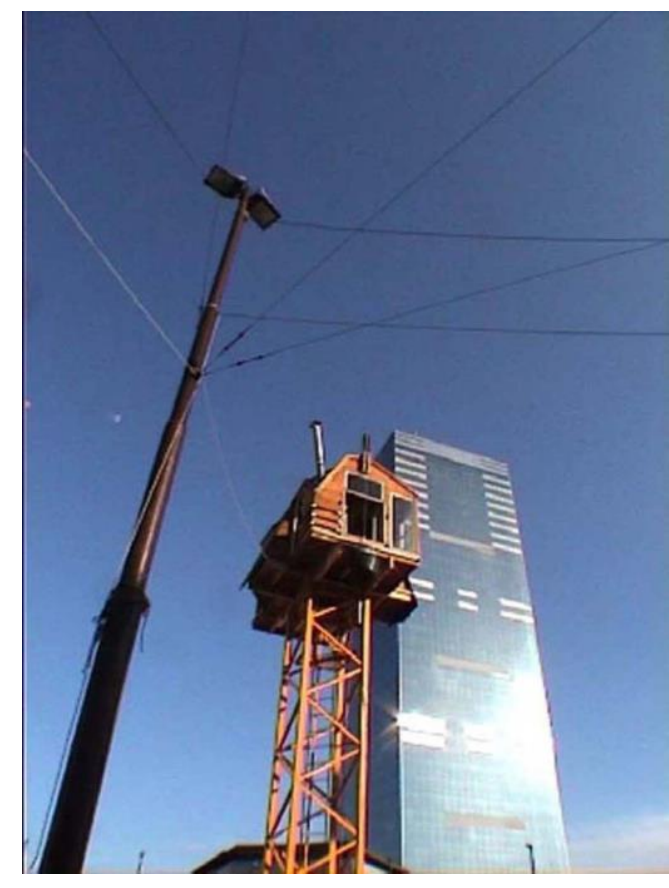

Image 3: Bara/ke (2000). (c) Benjamin Verdonck. All rights reserved.

The 'diplomat's house' was located on Bara Square, a neighbourhood that was in those days considered "a dangerous non-place, [...] a space local and immigrant communities share with visitors". Through an apparent non-event, this street action aimed at leaving behind some ideas to revitalize the area, not in economic terms of urban development and gentrification, but in terms of environmental and social connections. Again, Verdonck here takes a pass at the role of the philosopher as diplomat. His temporary home triggered a good deal response from the local residents and connected with their ideas and expectations of home, environment and belonging.

Verdonck also inaugurated an interesting posthuman perspective on ecology. The 'narrative' developed from the unforeseeable mesh with which the artist engaged, incorporating not only human beings, but also mere 'things' from the environment. During the project on Bara Square, Verdonck collected all the waste that was produced. If he found a small iron ring, for instance, he would take a card and write down his thoughts on finding it. These items are an indispensable part of the narrative that is developed. Other small, seemingly worthless objects that he collects are shopping lists, pieces of paper and (lost) gloves. To him, these things are the starting point for potentiality, for a contribution in "agency as vibrant matter" (Bennett 2009, 7). Verdonck himself put it as follows:

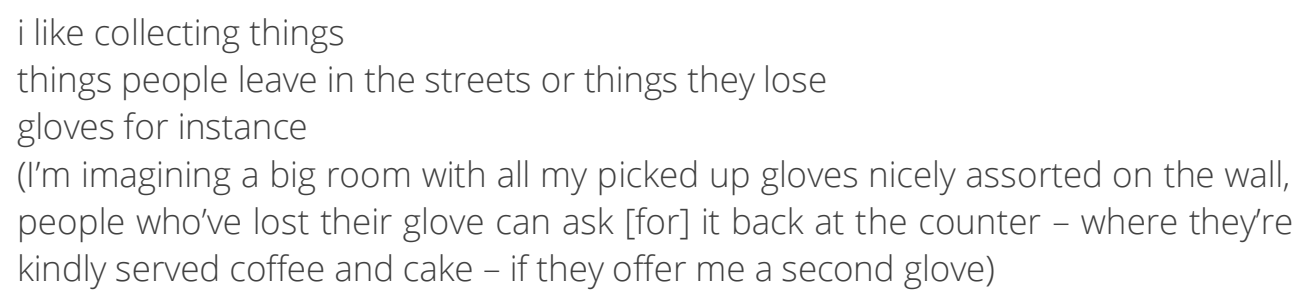




\section{HE'S IN THE GUTTER MEANS THAT HE'S NOT DOING WELL \\ THAT'S PATHETIC BUT THAT ALSO MEANS THERE'S A \\ POSSIBILITY TO DO SOMETHING ABOUT IT \\ IF YOU PICK UP THINGS, THEY CHANGE \\ THEY'RE PICKED UP THINGS NOW AND THAT IS \\ SOMETHING TOTALLY DIFFERENT (Verdonck 2008, 435-436)}

The little things Verdonck collects and displays in his tree houses are not what we would conventionally call 'beautiful', or 'attractive'. On the contrary, these objets trouvés are often 'dirty' and 'ugly', as they come from the gutter. However, they convey a feeling of concreteness and reality, carrying and radiating a different kind of beauty; they create, in their repetitive display, a sense of unreal reality. These objects are rubbish, they come from the gutter, but they have become part of Verdonck's everyday life, which is inherently connected with his artistic practice and with ecological thoughts. They are no longer mere objects. They have changed, as Verdonck has picked them up from the gutter and has connected them with the mesh of the collective he encounters in the present.
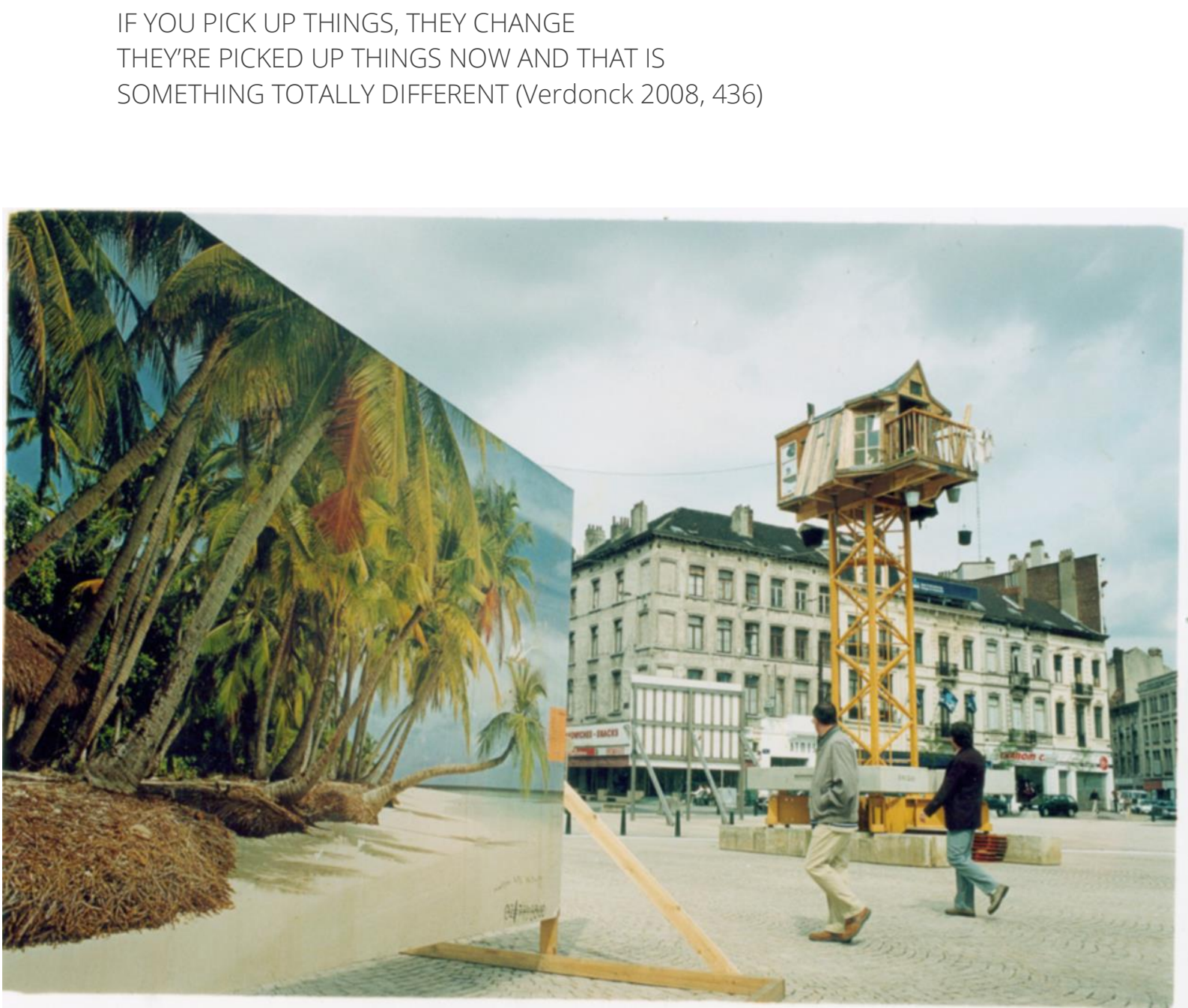
This discourse denotes a paradigm shift concerning the notion of 'eco-activist labour' engaged with social 'change'. From this posthuman perspective, change is not only derived from concrete action by human beings, gathered in homogeneous communities, geared by clear aims and clear instructions, displayed in manifestos and slogans. Verdonck's eco-activist labour has more to do with philosophical potentialities of becoming, with allowing capacities to emerge, rather than with a single ideal of changing the world through heroic action or market-driven business plans or models of gentrification. Moreover, activists in fact adopt a neo-liberal discourse themselves when they measure the value of their performances merely by success, in the sense of the effectiveness of their interventions towards social change. Following one ideal and a set of rules that promise the highest chance of success is likewise a market-based mechanism. Is activism hence developing towards commodity activism in neoliberal times (Mukherjee and Banet-Weiser)?

Verdonck deliberately challenges any neo-liberal discourse. First, the objects he finds and 'exhibits' have no market value whatsoever. What can a person do with one glove, anyway? Verdonck is not interested in the functional use of these objects. He does not consider them as tools in targeted action or beneficial activist labour. Likewise, Verdonck does not 'sell' the coffee or tea from a market-oriented perspective, in order to make profit.

But Verdonck doesn't collect these things out of mere nostalgia either. Rather than clinging on to a narrow affective register of nostalgic feelings and anthropocentric moods, Verdonck philosophically engages with a posthuman notion of ecology. Man's alienation from 'nature', as it has been lamented in Romanticism, is substituted here by a confident discourse of interconnecting in the 'now'. Nature is not revisited or staged as an ideal or origin we have become alienated from, but as part of our mutual becoming in a posthuman notion of ecology. This involves a 'pressure on the now' (Phelan and Chaudhuri 2013) within the constellation of the collective as interdependent, an implication in what Bennett calls a distributed agency with vibrant matter. Ethics, here, is detached from moralism. As Jane Bennett puts it:

\section{An understanding of agency as distributive and confederate thus reinvokes the need to detach ethics from moralism and to produce guides to action appropriate to a world of vital, crosscutting forces (Bennett 2009, 38).}

Verdonck has integrated the process of brewing coffee into his performance installation. The everyday gesture of drinking coffee or tea is part of his eco-activist labour. The coffee, tea and breakfast Verdonck serves is also food for thought. Of course, the unfolding narrative also integrates the visitor-spectator's ideas about the immediate urban environment. By integrating the act of brewing coffee into his art, the artist in fact percolates an acute critique of city branding and economically geared acts of gentrification. This critique, however, is not wrapped up in a clear, easily digestible message, for the performer-as-philosopher is a diplomat who does not seek to convert people to unanimous consensus. Rather, he creates a pragmatic situation that invites people to think through that which concerns them, in close interconnection with the environmental community in which they dwell. If the pragmatic interventions of Verdonck as an eco-diplomat of dissensus have any value whatsoever, it lies in his ability to fold the cultivated and rational 'know- 
all'-attitude into a never-ending process of negotiating heterogeneity. As performance scholar Efrosini Protopapa observes, diplomacy is "an act of negotiation" (Protopapa 2013, 4); it inaugurates "a specific relationship to sharing space and time with others, a specific set of strategies or tactics aimed at negotiation".7 The eco-artist-as-diplomat for that matter does not try to convince people of a Truth; he rather provides space to disagree, or, to put it in Jacques Rancière's words, a space for "dissensus" (Rancière 2010).

Following Rancière, the introduction of a third thing, owned by no one, is a way of dismantling the mechanism of equivalences and oppositions that supports consensus in thought. What Rancière desires art - including art in public space - to inaugurate is "simply scenes of dissensus, capable of surfacing in any place and at any time" (Rancière 2009. 48). He calls this a process of "political subjectivation" (48). It differs from a total process of subjection as it does not concern creating harmoniously structured collective bodies, but "the collectivation of capacities invested in scenes of dissensus" (Rancière 2009, 49). An eco-artist as diplomat invests in a "dissensual community" (Rancière 2009, 59); the community s/he encounters is structured by disconnection, but it is at the same time temporarily tied together by "sensation", by "a certain sensory fabric" (Rancière 2009, 56). In Verdonck's case, this entails the embodied labour of drinking tea together and thinking with and through the concrete environment.

Rather than conveying a clear message or communicating his ecological aims in order to instruct the audience to take direct action, Verdonck performs the labour of a philosopher as diplomat, asserting several ecological claims. He does not enact power, he desires, as a performerphilosopher-diplomat, to leave "the question of the number of the collective open, a question that, without him, everyone would have a tendency to simplify somewhat" (Latour 2004, 217). He does not refer to a debated conviction, but to the complexity of the debate itself. In raising ecological matters, Verdonck is, like the philosopher and the diplomat, at the same time "explorer, investigator and sensor", "more twisted than the moralist, less procedural than the administrator, less wilful than the politician, more bent than the scientist, more detached than the explorer of markets", (Latour 2004, 217). But, above all, I would add, Verdonck is also a performer, someone who can play with convictions.

The visitors-spectators are also engaged in this play, as they co-create 'the narrative'. They are not distant observers; they are connected in the artwork. In rethinking the relation between philosophy, ethics, the environment and ecology, Verdonck and the visitor-spectators as cocreators inherently connect ecology with thinking through ways of living together. Ecology for that matter moves into the direction of what Félix Guattari in The Three Ecologies refers to as "the ethicoaesthetic aegis of an ecosophy" (Guattari 2000, 41): a contraction of ecology and philosophy that connects the environmental with a reflection on the psychic production of subjectivity and social relations. Or again, it moves towards what Isabelle Stengers, following Deleuze and Spinoza, calls "ethology" to refer to an irreducible interconnection of ethics and ecology.

It is confidence in the emergence of capacities, in the possibilities of becoming, not lamented alienation that invites people to think. In dismantling the Western Romantic tradition of reclusive 
life, Verdonck and his visitor-spectators engage with a mode of ecological thinking in the present that is inherently connected with notions of relationality and with ways of living together. Thinking and drinking tea in Benjamin Verdonck's Bara/ke creates a situation that escapes moralism and fatal destiny, in order to fold into differential futures and possible worlds. Verdonck's belief in the possibility to change something by merely picking up things, be it a lost object or a marginalized idea, points at the artist's confidence in moving forward from a 'pressure on the now'.

Notes

\begin{abstract}
${ }^{1}$ Although the detrimental effects of an expanding industry had been condemned in earlier scientific articles and reports, the ecological conviction only truly spreads in the sixties (see also Stalpaert and Byttebier 2014).

2 David Foreman, one of the founders of Earth First! actually entitled his memoirs Confessions of an Eco-Warrior, (1991). See also the more critical writings of Rik Scarce (2006).

${ }^{3}$ Ron Arnold (1997), Ecoterror. The Violent Agenda to Save Nature.

${ }^{4}$ The activists of Earth First! envision a revolutionary movement with their motto "No Compromise in the defense of Mother Earth".

${ }^{5}$ As Katja Čičigoj aptly remarks: "Is there anything left here that could be called 'specific' at all?" (Čičigoj 2013: 38).

${ }^{6}$ Likewise, in Hirondelle/Dooi vogeltje/The Great Swallow (Brussels, 2004; Birmingham, 2005; Rotterdam, 2006), Verdonck lived in an enormous swallow's nest thirty-one metres in the air for a week. On the ground below, between the passers-by, was a gigantic egg. In Brussels, the bird nest was built in front of the administrative center of Brussels. In Birmingham, it was built in front of the Rotunda building, next to the Bullring shopping center in the middle of Birmingham.

7 In the paper "Diplomatic Bodies. Redirecting, Sidetracking, Deflecting, Bypassing" (2013), Efrosini Protopapa reflects on a choreographic project in which she develops the notion of diplomatic bodies, drawing on The Ignorant Schoolmaster by Jacques Rancière and Richard Sennett's discussion of "everyday diplomacy" in his book Together: The Rituals, Pleasures and Politics of Cooperation (2012).
\end{abstract}

\title{
Works Cited
}

Amory, Dita. 2007. "The Barbizon School: French Painters of Nature." Heilbrunn Timeline of Art History. The Metropolitan Museum of Art, March. Accessed 28 May 2013. http://www.metmuseum.org/toah/hd/bfpn/ hd bfpn.htm.

Arnold, Ron. 1997. Ecoterror: The Violent Agenda to Save Nature. Bellevue WA: Free Enterprise Press.

Arons, Wendy. 2007. "Review of Nature Performed: Environment, Culture and Performance, ed. Bronislaw Szerszynski, Wallace Heim and Claire Waterton, and Performing Nature: Explorations in Ecology and the Arts, eds. Gabriella Giannachi and Nigel Stewart." Theatre Journal 59 (4): 687-689. http://dx.doi.org/10.1353/tj.2008.0038.

Bennett, Jane. 2009. Vibrant Matter. A Political Ecology of Things. Durham NC: Duke University Press.

Čičigoj, Katja. 2013 "Up to Nature: the Continuation of Ego-Ecology?" Maska 153-154: 38-45.

Foreman, David. 1991. Confessions of an Eco-Warrior. New York: Crown Publications.

Frances Lee, Martha. 1995. Earth First! Environmental Apocalypse. Syracuse: Syracuse University Press, 1995. 
Fraser, Genevieve Thomson. Preface. "Giants in the Wilderness: A One-Act Play Forestry Chautauqua." The Drama Circle. Art for Life, 9 July 2008. Accessed 6 August 2012. http://thedramacircle.blogspot.be/p/ecotheatergiants-in-wilderness-by.html.

Gay, Kathlyn. 2012. American Dissidents: An Encyclopedia of Activists, Subversives, and Prisoners of Conscience. Volume 1. Santa Barbara CA: ABC-CLIO.

Guattari, Félix. 2000. The Three Ecologies. Translated by lan Pindar and Paul Sutton. London: Athlone.

Kelleher, Joe. 2013. "You Promised Me Ten Thousand people." Maska 153/154: 24-29.

Keller, David R., and Frank B. Golley. 2000. "Introduction." In The Philosophy of Ecology: From Science to Synthesis, edited by David R. Keller and Frank B. Golley, 1-19. Athens GA: University of Georgia Press.

Latour, Bruno. 2004. Politics of Nature: How to Bring the Sciences into Democracy. Translated by Catherine Porter. Cambridge and London: Harvard University Press.

Manes, Christopher. 1990. Green Rage: Radical Environmentalism and the Unmaking of Civilization. Boston: Little, Brown.

Massumi, Brian and Erin Manning. 2009. "History Through the Middle. Between Macro and Mesopolitics. An Interview with Isabelle Stengers." Inflections 3. Accessed 8 August 2013. http://www.senselab.ca/inflexions/volume 3/node i3/stengers en inflexions vol03.html.

Morton, Timothy. 2007. Ecology Without Nature. Rethinking Environmental Aesthetics. Cambridge and London: Harvard University Press.

___. The Ecological Thought. 2010. Cambridge MA: Harvard University Press.

Mukherjee, Roopali and Sarah Banet-Weiser. 2012. Commodity Activism. Cultural Resistance in Neoliberal Times. New York: New York University Press.

Phelan, Peggy and Una Chaudhuri. 2013. "Performance in an Expanded Temporal Field." Paper presented at Now Then. Performance and Temporality, Performance Studies International conference 19, Stanford University, June 26-30.

Protopapa, Efrosini. 2013. "Diplomatic Bodies. Redirecting, Sidetracking, Deflecting, Bypassing." Paper presented at the Choreography \& Corporeality Working Group of the FIRT/IFTR World Congress, Re-Routing Performance, Barcelona, July 22-26.

Rancière, Jacques. 2009. The Emancipated Spectator. London: Verso.

2010. Dissensus: On Politics and Aesthetics. London: Bloomsbury.

Rousseau, Jean-Jacques. 2011. Reveries of the Solitary Walker. Translated by Russell Goulbourne. Oxford: Oxford University Press.

Scarce, Rik. 2006. Eco-Warriors: Understanding the Radical Environmental Movement. Walnut Creek CA: Left Coast Press.

Shackelford, George T.M. and Fronia E. Wissman. 2002. Impressions of Light: The French Landscape from Corot to Monet. Boston: MFA Publications.

Stalpaert, Christel and Karolien Byttebier. 2014. "Art and Ecology. Scenes from a Tumultuous Affair." In The Ethics of Art. Ecological Turns in the Performing Arts, edited by Guy Cools and Pascal Gielen, 59-87. Amsterdam: Valiz.

Thoreau, Henry David. 1995. Walden; or, Life in the Woods. Mineola NY: Dover Publications.

Van Dyke, Fred. 2008. Conservation Biology: Foundations, Concepts, Applications. London: Springer.

Verdonck, Benjamin. 2008. Werk/Some Work. Ghent: MER. Paper Kunsthalle/Campo. 


\section{Biography}

Christel Stalpaert is Professor of Theatre, Performance and Media Studies at Ghent University (Belgium) where she is director of the research unit S:PAM (Studies in Performing Arts and Media). Her main areas of research are the performing arts, dance and the new media at the meeting-point of philosophy. She has contributed to many journals such as Performance Research, Text \& Performance Quarterly, Contemporary Theatre Review and Dance Research Journal, and edited such works such as Deleuze Revisited: Contemporary Performing Arts and the Ruin of Representation (2003), No Beauty for Me There Where Human Life is Rare: on Jan Lauwers' Theatre Work with Needcompany (2007) and Bastard or Playmate? Adapting Theatre, Mutating Media and the Contemporary Performing Arts (2012). She is editor in chief of Documenta, Studies in Performing Arts and Film (Academia Press Ghent) and member of the editorial board of Theater Topics (Amsterdam University Press). She is currently finishing her book on Performing Violent Conflicts and Traumas: Towards an Embodied Poetics of Failure.

(c) 2015 Christel Stalpaert 